Security/Capital 
Dedicated to Andie and Lucas for their love and support 


\title{
Security/Capital
}

\section{A General Theory of Pacification}

\author{
George S. Rigakos
}


Edinburgh University Press is one of the leading university presses in the UK. We publish academic books and journals in our selected subject areas across the humanities and social sciences, combining cutting-edge scholarship with high editorial and production values to produce academic works of lasting importance. For more information visit our website: www. edinburghuniversitypress.com

(c) George S. Rigakos, 2016

Edinburgh University Press Ltd

The Tun - Holyrood Road

12(2f) Jackson's Entry

Edinburgh EH8 8PJ

Typeset in 11/13 Sabon by Servis Filmsetting Ltd, Stockport, Cheshire and printed and bound in Great Britain by CPI Group (UK) Ltd, Croydon CR0 4YY

A CIP record for this book is available from the British Library

ISBN 9781474413664 (hardback)

ISBN 9781474413688 (webready PDF)

ISBN 9781474413671 (paperback)

ISBN 9781474413695 (epub)

The right of George S. Rigakos to be identified as the author of this work has been asserted in accordance with the Copyright, Designs and Patents Act 1988, and the Copyright and Related Rights Regulations 2003 (SI No. 2498). 